\title{
Elemental Chemical Analysis by X-ray Fluorescence of Calcarenite Stones Used in Historical Monuments Building of Rabat (Morocco)
}

\author{
Y. El Rhaffari ${ }^{1}$, M. Hraita ${ }^{1}$, A. Rahmouni ${ }^{1}$, A. Samaouali ${ }^{1}$, M. Boukalouch ${ }^{1}$, Y. Geraud ${ }^{2}$ \\ ${ }^{1}$ Thermodynamic-Energy Team, Center of Research in Energy,Faculty of Science, Mohammed V University, \\ P.O. Box 1014,Rabat, Morocco, Email: ayounes1@ hotmail.com \\ ${ }^{2}$ Université de Lorraine, Ecole Nationale Supérieure de Géologie, UMR 7359-Géo Ressources rue du Doyen \\ Marcel Roubault TSA 70605, 54518 Vandoeuvre Les Nancy Cedex, France
}

\begin{abstract}
A good knowledge of chemical properties, thermophysical and petrophysical parameters, makes it possible to understand the mechanisms of alteration of historical monuments, and to predict solutions limiting their evolution.

The main objective of this work is chemical analysis by X-ray fluorescence spectrometry on calcarenite stones, often used as a building material for historical monuments of Rabat (Morocco), in order to identify the nature of the rock.

The elemental chemical composition shows high concentrations of $\mathrm{CaO}$ and $\mathrm{SiO}_{2}$, which confirms that the main phases of the calcarenite rock studied are calcite and quartz. These are the characteristic minerals of calcareous rocks.
\end{abstract}

\section{Introduction}

The main objective of this work is to determine the mineralogical properties of calcarenite rocks, often used as building materials for historical monuments of Rabat

Calcarenite was the material used to build the historical monuments of the city of Rabat, it was used to build the Roman and Islamic buildings of Chellah $[1,2]$.

The experimental approach consists in studying Xray fluorescence spectrometry (XRF), in order to identify the nature of the rock and to better understand the processes of heat and fluid transfer in material.

Chemical analyzes of several samples of calcarenites Plio-Quaternary in the city of Rabat indicate that the main component of these deposits is calcium carbonate $\left(\mathrm{CaCO}_{3}\right)$, its content varies between 50 and $57 \%$, reflecting theimportance of bioclasts marines. In contrast, the content of silica $\left(\mathrm{SiO}_{2}\right)$, which is in the form of quartz grains, is very low $[3,4,5]$.

\section{Description of method of work}

\subsection{Sampling}

The material tested sample is a calcarenite stone,sampled from a quarry located near the historicalmonument of Chellah "figure1".

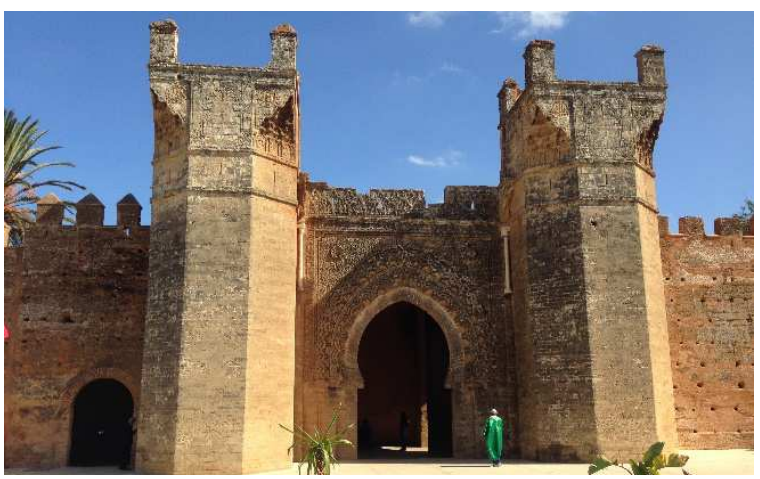

Fig. 1. Main gate of the Chellah monument

Geologically, it is a calcareous limestone, ofPlioQuaternary age in the form of a system ofdune ridges running parallel along the Atlanticcoast. The deposit calcarenite took place under theaction of a substantially aeolian dynamics withplenty of round quartz grains mats whichremobilized sand beach, and by the largehorizontal stratifications [6].

Ten cylindrical samples were extracted from the calcarenite material by an Diamond Drill with Water Cooled Bits "figure 2". The samples were placed in a forced ventilation oven, where they were dried at a 
temperature of $55^{\circ} \mathrm{C}$, until their mass became constant.

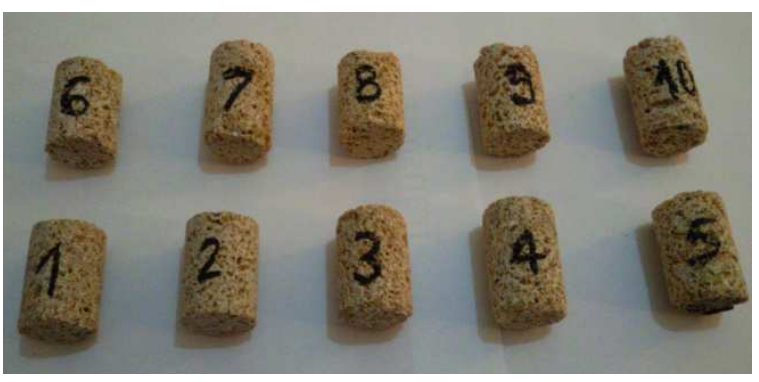

Fig. 2. Ten cylindrical samples extracted by coring

\subsection{X-ray fluorescence spectrometry}

Chemical analysis by X-ray fluorescencespectrometry was carried out for the identification of the mineral species of the stone studied. The apparatus used is an Axios of Panalytical, which requires samples in powder form. It is a sequential spectrometer with a measuring channel on a single goniometer covering the complete range of measurement of Beryllium to Uranium elements. It is controlled by a microprocessor for maximum flexibility and the entire system is controlled by a computer with spectrum analysis and processing software.

During X-ray fluorescence spectroscopy (XRF), the atoms contained in the reference and analytical substances are excited by the spectra of lines and braking of an X-ray tube to emit their characteristic $\mathrm{X}$-ray fluorescence. Radiation emitted by the sample is fractionated by monochromatization on crystal analyzers in the spectrometer, so that it is possible to measure the intensities of the different spectral lines or spectral regions (wavelengths dispersive).

After correction of matrix effects and line superposition, the measured intensity of an elementary line serves as a gauge for the concentration of the element.

\section{Results and interpretations}

We have analyzed the powders of ten samples by Xray fluorescence spectrometry (XRF). The elemental chemical composition "Table 1" shows high contents of $\mathrm{CaO}$ with percentages between $45.12 \%$ and $50.96 \%$, and a non-negligible amount of $\mathrm{SiO} 2$ with percentages between $4.10 \%$ and $11.39 \%$. In presence of traces of $\mathrm{Al}_{2} \mathrm{O}_{3}$ (between $0.45 \%$ and $1.65 \%$ ), $\mathrm{MgO}$ (between $0.54 \%$ and $0.78 \%$ ), $\mathrm{Fe}_{2} \mathrm{O}_{3}$ (between $0.38 \%$ and $1.27 \% \mathrm{Na}_{2} \mathrm{O}$ (between $0.13 \%$ and $0.19 \%$ ), $\mathrm{SrO}$ (between $0.05 \%$ and $0.15 \%$ ), $\mathrm{P}_{2} \mathrm{O}_{5}$ (between $0.07 \%$ and $0.11 \%), \mathrm{SO}_{3}(0.05 \%$ and $0.09 \%), \mathrm{Cl}$ (between $0.03 \%$ and $0.04 \%$ ), $\mathrm{TiO}_{2}$ (between $0 \%$ and $0.08 \% \%$ ) and $\mathrm{MnO}_{2}$ (between $0 \%$ and $0.02 \%$ ).

\section{CONCLUSION}

Chemical elemental composition shows that the principal phases of the calcarenite rock of Rabat are calcite and quartz; they are characteristic minerals of calcareous rocks. This result is in agreement with the results found by Samaouali [7].

A good knowledge of the mineralogical composition, which plays an important role in phenomena of thermal transfers, capillary and evaporation, therefore makes it possible to better understand the mechanisms of alteration of historic monuments and to envisage solutions limiting their progress.

Table 1. Results of chemical analysis by (XRF)

\begin{tabular}{|c|c|c|c|c|c|c|c|c|c|c|c|c|c|c|c|}
\hline & $\mathbf{C a O}$ & $\mathbf{P , a}, \mathbf{F}$ & $\mathbf{S i O}_{\mathbf{2}}$ & $\mathbf{A}_{\mathbf{1} 2} \mathbf{O}_{\mathbf{3}}$ & $\mathbf{M g O}$ & $\mathbf{F e}_{\mathbf{2}} \mathbf{O}_{\mathbf{3}}$ & $\mathbf{N a}_{\mathbf{2}} \mathbf{O}$ & $\mathbf{S r O}$ & $\mathbf{P}_{\mathbf{2}} \mathbf{O}_{\mathbf{5}}$ & $\mathbf{S O}_{\mathbf{3}}$ & $\mathbf{K}_{\mathbf{2}} \mathbf{O}$ & $\mathbf{C l}$ & $\mathbf{T i O}_{\mathbf{2}}$ & $\mathbf{M n O}_{\mathbf{2}}$ & $\mathbf{S u m}$ \\
\hline Ech1 & 50,83 & 41,37 & 5,40 & 0,66 & 0,71 & 0,49 & 0,16 & 0,10 & 0,08 & 0,07 & 0,05 & 0,04 & 0 & 0 & 100 \\
\hline Ech2 & 50,96 & 41,1 & 5,42 & 0,74 & 0,68 & 0,51 & 0,19 & 0,09 & 0,07 & 0,09 & 0,06 & 0,04 & 0 & 0 & 100 \\
\hline Ech3 & 49,23 & 40,8 & 7,08 & 1,01 & 0,62 & 0,72 & 0,15 & 0,06 & 0,08 & 0,05 & 0,06 & 0,03 & 0,04 & 0 & 100 \\
\hline Ech4 & 45,12 & 39,11 & 11,3 & 1,65 & 0,75 & 1,27 & 0,18 & 0,05 & 0,11 & 0,05 & 0,17 & 0,03 & 0,08 & 0 & 100 \\
\hline Ech5 & 50,19 & 43,52 & 4,37 & 0,45 & 0,55 & 0,38 & 0,13 & 0,15 & 0,08 & 0,04 & 0,02 & 0,03 & 0,02 & 0 & 100 \\
\hline Ech6 & 45,68 & 46,52 & 5,77 & 0,61 & 0,54 & 0,41 & 0,13 & 0,08 & 0,07 & 0,06 & 0,05 & 0,03 & 0 & 0 & 100 \\
\hline Ech7 & 49,88 & 41,64 & 5,26 & 1,27 & 0,78 & 0,59 & 0,16 & 0,06 & 0,08 & 0,06 & 0,09 & 0,03 & 0,04 & 0 & 100 \\
\hline Ech8 & 47,44 & 42,19 & 7,50 & 0,93 & 0,61 & 0,70 & 0,16 & 0,09 & 0,10 & 0,05 & 0,07 & 0,03 & 0,05 & 0,02 & 100 \\
\hline Ech9 & 50,9 & 43,05 & 4,10 & 0,47 & 0,56 & 0,39 & 0,15 & 0,14 & 0,09 & 0,05 & 0,02 & 0,03 & 0 & 0 & 100 \\
\hline Ech10 & 50,88 & 41,3 & 5,45 & 0,68 & 0,60 & 0,49 & 0,16 & 0,10 & 0,10 & 0,06 & 0,04 & 0,03 & 0,03 & 0,02 & 100 \\
\hline
\end{tabular}




\section{References}

1. Bellitir D., 1998. Etude géologique et techniques des calcarénites de la côte atlantique et des calcaires mésozöques des rides prérifaines, utilisés au Maroc dans les constructions anciennes et actuelles. Thèse de Doctorat, Université de GAND, Belgique, 268p.

2. Bellitir D., Nijs R., Asebriy L et Aberkan M., 1998. Evolution de la calcarénite dans les constructions; vitesse d'altération en fonction des facteurs naturels et industriels. Mines, Géologie et Energie, 57 : 83-88.

3. H. Azouaoui, N. El Hatimi, and N. El Yamine, Plio-Quaternary formations of the Casablanca area (Morocco): sedimentological and geotechnical aspects, Bull Eng Geol Environ, 2000, 59, 59 .
4. R. Benboughaba, Phd thesis, Etude Sédimentologique et Géophysique des formations littorales plio-quaternaires de l'axe RabatKénitra(Maroc), Université Mohammed V of Rabat, Morocco, 2001.

5. A. Samaouali, L. Laânab, Y. Geraud, A. Nounah, and M. Boukalouch, Experimental study of chemical deterioration of chellah monument stones, Phys. Chem. News, 2008, 44, 103.

6. Y. El Rhaffari, M. Hraita , A. Samaouali, M. Boukalouch and Y. Géraud, Thermal and petrophysical characteristics of calcarenite rocks used in the construction of monuments of Rabat, Romanian Journal of Materials 2014, 44(2), 153.

7. A. Samaouali, Processus d'altération et de transfert de fluides dans les pierres calcarénites du monument Chellah- Rabat, Phd thesis, University Mohammed V of Rabat, Morocco, 2011. 